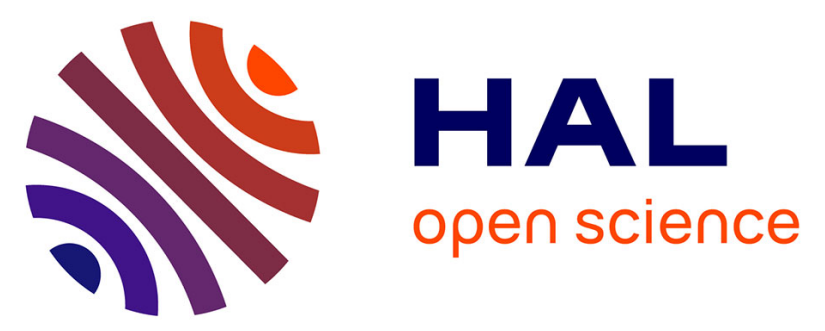

\title{
Behavior patterns related to the agricultural practices in the production of Persian lime (Citrus latifolia tanaka) in the seasonal orchard
}

Gregorio Fernández Lambert, Alberto Aguilar-Lasserre, Catherine Azzaro-Pantel, Marco Augusto Miranda Ackerman, Rubén Purroy Vázquez, María del Rosario Pérez Salazar

\section{To cite this version:}

Gregorio Fernández Lambert, Alberto Aguilar-Lasserre, Catherine Azzaro-Pantel, Marco Augusto Miranda Ackerman, Rubén Purroy Vázquez, et al.. Behavior patterns related to the agricultural practices in the production of Persian lime (Citrus latifolia tanaka) in the seasonal orchard. Computers and Electronics in Agriculture, 2015, 116, pp.162-172. 10.1016/j.compag.2015.06.007 . hal-02134881

\author{
HAL Id: hal-02134881 \\ https://hal.science/hal-02134881
}

Submitted on 20 May 2019

HAL is a multi-disciplinary open access archive for the deposit and dissemination of scientific research documents, whether they are published or not. The documents may come from teaching and research institutions in France or abroad, or from public or private research centers.
L'archive ouverte pluridisciplinaire HAL, est destinée au dépôt et à la diffusion de documents scientifiques de niveau recherche, publiés ou non, émanant des établissements d'enseignement et de recherche français ou étrangers, des laboratoires publics ou privés. 


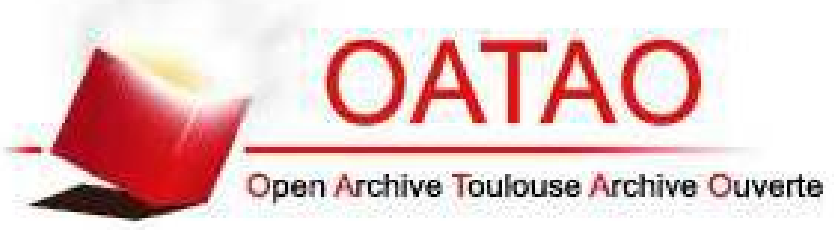

\section{Open Archive Toulouse Archive Ouverte (OATAO)}

OATAO is an open access repository that collects the work of some Toulouse researchers and makes it freely available over the web where possible.

This is an author's version published in: http://oatao.univ-toulouse.fr/20592

Official URL: https://doi.org/10.1016/j.compag.2015.06.007

\section{To cite this version:}

Fernández Lambert, Gregorio and Aguilar Lasserre, Alberto and Azzaro-Pantel, Catherine and Miranda Ackerman, Marco Augusto and Purroy Vázquez, Rubén and del Rosario Pérez Salazar, María Behavior patterns related to the agricultural practices in the production of Persian lime (Citrus latifolia tanaka) in the seasonal orchard. (2015) Computers and Electronics in Agriculture, 116. 162-172. ISSN 0168-1699

Any correspondence concerning this service should be sent to the repository administrator: tech-oatao@listes-diff.inp-toulouse.fr 


\title{
Behavior patterns related to the agricultural practices in the production of Persian lime (Citrus latifolia tanaka) in the seasonal orchard
}

\author{
Gregorio Fernández Lambert ${ }^{\mathrm{a}}$, Alberto Aguilar Lasserre ${ }^{\mathrm{b}}$, Catherine Azzaro-Pantel ${ }^{\mathrm{c}, *}$, \\ Marco A. Miranda-Ackerman ${ }^{c}$, Rubén Purroy Vázquez ${ }^{\mathrm{d}}$, María del Rosario Pérez Salazar ${ }^{\mathrm{d}}$ \\ a Instituto Tecnológico Superior de Misantla, km. 1.8 Carretera a Loma del Cojolite, C.P. 93821 Misantla, Veracruz, Mexico \\ b Instituto Tecnológico de Orizaba, Avenida Oriente 9 No. 852, Col. Emiliano Zapata, C.P. 94320 Orizaba, Veracruz, Mexico \\ ${ }^{c}$ Université de Toulouse, Laboratoire de Génie Chimique, LGC UMR 5503, CNRS INP-ENSIACET, 4, Allée Emile Monso, BP 84234, F-31432 Toulouse, France \\ ${ }^{\mathrm{d}}$ Instituto Tecnológico Superior de Tantoyuca, Desviación Lindero Tametate, Colonia la Morita, C.P. 92101 Tantoyuca, Veracruz, Mexico
}

Keywords:

Behavior patterns

Persian lime

Agricultural practices

Expert system

\begin{abstract}
A B S T R A C T
Production of the Persian lime (Citrus latifolia tanaka) has been the main objective of several studies related to the problem of low performance of yield and fruit quality in the orchard, attributed among different technological factors to the minimal application of Good Agricultural Practices (GAP) and to the cultural aspects of the producer. This paper contributes to the recognition of the behavior patterns of GAP for seasonal orchard (SO), to allow the Persian lime producers to make the right decisions assessing and improving the management of their orchards. To identify the behavior patterns in the Persian lime production process an expert system (ES) based on fuzzy logic proposed by Fernández et al. (2014) has been used, in which a set of inference rules based on the knowledge of experts in this field is encoded to explain the interrelationship of the agricultural practices and uncertainties in the production of Persian lime: Pruning, Soil nutrition, Pests Control, Planting density, Tree production, Wind, Rainfall. The ES simulates from agricultural practices and uncertainties, the Persian lime production system in three stages of fruit growth, which represent the fuzzy models of the ES: flowering, bud, and fruit. The manipulation of the agricultural practices in the ES allowed to model production scenarios for SO of Persian lime, and helped to identify behavior patterns in these practices with production yield and fruit quality. The results demonstrate that if prior to fertilization, the practice of "pruning" the tree is performed, orchard productivity increases. However, when the "pruning" (aesthetics or stressful) is performed less than $50 \mathrm{~mm}$ month $^{-1}$ of rain, even in optimal conditions of application of nutrients and pest control, the production yield is similar. The modeling scenarios of the ES provide information regarding behavior patterns to the producer, and the interrelation of agricultural practices in uncertain environments of rain and wind in order to improve the decision-making process in Persian lime production.
\end{abstract}

\section{Introduction}

Nowadays citrus production is the main activity of the producers of fruit trees in the world (104 million tons, $7.1 \times 106 \mathrm{ha})$ and the countries with higher production are Brazil, China, India, USA, Mexico and Spain, as well as many other tropical and subtropical regions in the world. There are six citrus groups of economic interest: sweet orange [Citrus sinensis (L.) Osb.], common mandarin (Citrus reticulata Blanco), Satsuma mandarin (Citrus unshiu Marc), grapefruit (Citrus paradisi Macf.), lemon (Citrus lemon Burm. f.) and lime (Citrus aurantifolia L.) (Agustí et al., 2014).

\footnotetext{
* Corresponding author.

E-mail address: Catherine.AzzaroPantel@ensiacet.fr (C. Azzaro-Pantel).
}

The Persian lime (Citrus latifolia tanaka) is mainly grown in the Gulf Coast of Mexico (Veracruz, Tabasco, and Yucatan); this region contributes $30 \%$ of the total Mexican production. Its cultivation in Mexico among farmers in the region of Martínez de la Torre, Veracruz, was promoted by the soft drink company Coca Cola to use the citric acid as raw material for soda, however Persian limes harvested did not satisfy the characteristics specified by the company (too much juice and little oil) and the company lost interest of the crop in the region. As a result, producers decided to introduce it into the U.S. market through Texas for distribution within the country under the scheme followed by the Florida producers (González, 2011).

Six research areas related to poor performance of the lime production system where identified by the Veracruz (region) Research and Development Network in Citrus in 2003 (REVIDEC, 2003): food 
safety, rootstocks, cultural practices, diagnostic studies, irrigation, diffusion and support. On the other hand, Becerra et al., 2009, in their work on the characterization of the citrus supply chain in the state of Veracruz concluded that there are two particular problems with Persian lime: first, in addition to the corresponding technological and cultural management practices, Persian lime producers refer to a poor quality of fruit for export, and low production yields of their orchards; which corresponds with that reported for Mexico by the Food and Agriculture Organization (FAO) in 2010 on average by 13.74 ton ha ${ }^{-1}$, and of that reported by countries like United States of America in the order of 34.69 ton $\mathrm{ha}^{-1}$.

In addition to GAP, a successful plantation of Persian lime or any other perennial species begins with the quality of the plant (Curti et al., 2000), without forgetting that there are other factors such as temperature, light intensity, rainfall, water stress, among other factors that the producer cannot control and influence in the phenology and affects the production yield and the quality of the fruit (Chacín et al., 2012). Therefore the importance of characterizing the production system of Persian lime in the orchard in order to identify the variables that impact the production yield and the quality of the fruit, as well as model the behavior of those uncertain parameters that can interfere at any given time in the fruit production is of paramount importance.

In this investigation the authors assume that the production yield and the percentage of the quality of the fruit to export that the producer can harvest - depends on the level of technology involved in their agricultural practices and growing conditions. This means that producer revenues depend not only on the harvested production volume but also on the quality of fruit obtained.

Improved performance on the quality and yield per hectare can significantly affect the producer revenues, as well as the fruit exporters (frequently the packaging company) (Miranda-Ackerman et al., 2014). This premise focuses our research to identify patterns of behavior in the agricultural practices involved in the production of Persian lime for the purpose of building a knowledge database to support the decision task in the agricultural practices management in the production of Persian lime, which translates into a higher revenue for the producer and a better quality of life for the farming families.

Pattern recognition is a multidisciplinary work whose main objective is to identify, characterize, classify and predict physical or abstract objects with the aim of extracting information to establish or predict the behavior of a response variable with respect to a control group, with the aim of guiding and managing the resources and efforts to optimize the system under study.

The behavior patterns recognition is usually based on a historical knowledge representation delineated as a set of data, as a result of a long period of observation of a complex dynamic system. Thus, the particular interest of researchers to identify behavior patterns lies mainly in predicting the behavior of an output variable with respect to a group of variables of influence, primarily, with the aim of managing resources in order to optimize the system under study.

The literature review shows that the use of AI techniques, such as data mining, knowledge discovery in serial measures, symbolic dynamics, RNAs, AGs, fuzzy logic, have spread to various industrial settings at the end of the last decade, and gradually to the agricultural sector; for instance, applying AI techniques to Agriculture, in order to solve agricultural field planning problems. The use of pattern recognition as a technique for improving the performance of crop production and crop quality has increased in popularity.

In this process of $\mathrm{AI}$ evolution, expert systems arose. An expert system can be understood as a computer program that captures human knowledge to solve problems in a specialized field and dependent on inference and specific experience of an expert. Hence, expert systems can become a tool to assist decision makers.
Concerning crop protection, taxonomy for crop protection expert systems is presented by Chakraborty and Chakrabarti (2008); they emphasize on the development of an expert system as a dynamic process typically conducted in two phases, the first deals with the diagnosis of the pest, and the second refers to the prescription of proper preventive or curative measures.

Shafinah et al. (2013) review proposals reporting the use of expert systems in pests and diseases management, to analyze and explain the tendency of the methodologies used for the diagnosis of pests and diseases in agricultural crops, identifying that the application of this technology is specific according to the crop type. They highlight, based on the selected works, pest and disease diagnosis as an important issue in agriculture and propose an expert system approach for better domain on this discipline.

Papageorgiou et al. (2011) propose an approach for predicting performance in the production of cotton crops in uncertain environments using soft computing technique of fuzzy cognitive maps (FCM). The FCM approach consists of nodes connected by directed edges, where the nodes represent the main factors affecting the crop production and the crop yield, such as texture, organic matter, $\mathrm{pH}, \mathrm{K}, \mathrm{P}, \mathrm{Mg}, \mathrm{N}, \mathrm{Ca}, \mathrm{Na}$, and directed edges show cause-effect relationships (weighted) between soil properties and yield of the cotton crop. The authors point out that the main advantage of this approach is its simple and flexible structure, which represents knowledge in visually manner and more descriptively, making it a useful tool to predict the cotton crop yield, therefore, improving crop management.

Srivastava (2012) highlights the negative impact of global warming on high temperatures, and its relation to the loss of soil nutrients due to agricultural intensity in citrus production. To minimize the negative impact of these parameters in production yield of the crop, proposes an integrated nutrient management, supported with foliar practice, and the application of organic fertilizers to fix carbon and nutrients to the soil, incorporated to a fertigation program to fix the minerals.

Ayman et al. (2014) present the design of an expert system to irrigate orchards based on knowledge of irrigation of citrus, mango and grapes, documented by agricultural experts of the Central Laboratory of Egypt (CLAES). The aim of the expert system is to optimize the use of water using the exact amount of water when the tree requires it. The variables included in the knowledge base of the ES are related to environmental factors such as temperature, soil type, water source, among other operations variables.

Neto et al. (2013) evaluated the horticultural performance of five rootstock patterns under irrigation and rainfed. The result showed that the application of irrigation caused more vegetative growth, increase on early fruiting, increase on fruit yield during the harvest season and out of season, increase on the efficiency, higher juice content and acidity, and a higher percentage of fruit suitable for export.

Several studies have reported the effect of irrigation in citrus cultivation with the aim of linking their impact to production performance through the stages of ripeness of citrus, and have shown that an important factor in the yield is the availability of water for the plant, proving that if an adequate irrigation takes place, an increase in the yield between 6 and $7 \mathrm{~kg}$ of fresh fruit per $\mathrm{m}^{-3}$ of water applied to the parcel is achieved, thus improving the quality of the fruit, and increasing the number of fruits to market (Carr, 2012). While the farmer can decide the best technologic practice for irrigation, the process is complicated when there is no water availability and its salinity characteristics are not suitable, or when the irrigation is made in general terms without taking into account the fruit production state -flowering or fruit formation-; which impacts at low levels of production, and the quality of fruit juice production (Syvertsen and Garcia, 2014; Consoli et al., 2014). 
Prolonged drought can retard growth and reduce fruit size; which undoubtedly affect production levels in the orchard.

In order to analyze the influence of agricultural practices and characteristics of the plantation in the production yield and fruit quality of Persian lime with characteristics for export to Japan, Corrales-García et al. (2009), supported by the Principal Component Analysis, study the variables in an irrigation orchard related to soil texture and soil topography, the orchard age, the number of fertilizers applications (for soil and foliage), the number of fungicides applications, type of pruning - the intensity and the frequency, row spacing, the height of the tree after pruning, irrigation frequency, the application of the growth regulator, the time between harvests during the high and low production periods.

Many expert systems have been developed in agriculture to help farmers in decision-making to obtain better production yield of corn, wheat, rice, sugarcane, sunflower, citrus, orange, mango, pineapple, apple, date palm, tomato, onion, chili, corn, garlic, cabbage, mushrooms, cucumber, beans, cucumber, lettuce, pepper, coffee, olive tea, crops, cotton, among others (Dath and Balakrishnan, 2013), and they can be classified according to farming activity in seven categories: Crop Management, Production Planning, Pest Management, Diagnostic systems, Maintenance systems, Process control systems, Marketing advice systems; and will undoubtedly continue to increase with the adoption of TICs by the farming community (Wankhede et al., 2014), an example is presented by Chevalier et al. (2012) especially for farmers with the possibility of accessing these technologies to improve their production results in the orchard.

Some proposals have used pattern recognition in the agricultural field; Romualdo et al. (2014) evaluate methods of digital image processing to develop an Artificial Vision System (AVS) to diagnose induced nitrogen deficiency in corn husks. The experiment was conducted in a greenhouse in which four level treatments were performed in combination of three stages of plant growth. The identification of the nutritional status of corn using a foliar chemical analysis requires sampling of leaves when the plant is at an advanced stage of development, which makes corrective action difficult in crop growth if the detection of a specific nutrient deficiency occurs; recognition of the nutritional status of the image-based plant in its early stages, can take action to improve the crop.

The literature review shows that over time, pattern recognition has been evolving and has become increasingly important in the industrial activity, to identify or predict the behavior of the variables of a system, it has become a common practice with applications in both structured and unstructured scenarios, to study family consumption, demand behavior, traffic environments, ergonomic environments, identity situations, classification, and recognition supported by linear and non-linear multivariate statistical techniques, such as: the principal component analysis, factor analysis of multiple component, covariate analysis, among other techniques such as the dynamic analysis, automatic learning, symbolic analysis or data mining (Anido, 1998; Bazan, 2005; Gupta, 2006; Aranguren Pachano, 2008).

In the last twenty years the study of variables and/or predicting them in unstructured environments has evolved significantly within the business sector by using techniques like Artificial Intelligence (AI) for pattern recognition. Among some of the most popular like simulation and data mining, artificial neural networks and Fuzzy Logic, this last two have demonstrated an ability to predict and/or estimate the behavior patterns and model complex problems based on classification, characterization and/or prediction.

Coping with the problem of low performance and fruit quality in the orchard highlights the need to study the behavior of the uncertain variables and parameters involved in the production of citrus with the purpose of modeling scenarios to recognize how to handle the production variables. In this sense, this paper describes the relationship and interdependence of a series of agricultural practices, which are explained as behavior patterns between agricultural practices and uncertain events for the production of Persian lime in the SO.

The scenario modeling carried out in the ES reported by Fernández et al. (2014), encodes the expertise of the producers, researchers and employers engaged in the citrus production. To model production scenarios, Fig. 1 describes the methodology for patterns recognition related to these practices.

The expert panel integration had as its main element the expertise in the production of Persian lime, and at this phase relapsed the scenario modeling conclusions. To feed the SE, databases regarding managing the orchard from 2005 to 2009 were available, from which crop scenarios were evaluated. The discovery of the behavior patterns allows the grower to evaluate production scenarios on the impact that would have the agricultural practices in crop yield and quality of fruit in the orchard.

The importance of this study should be reflected in the economic contribution for the producers through the maximization of their production and the quality of the fruit produced in their orchards.

\section{Material and methods}

\subsection{Description of the area and the study period}

The study was conducted in the town of Martínez de la Torre in the state of Veracruz, México for a six months period. This town is located in the northern region of the state, at coordinates $20^{\circ} 04^{\prime}$ north latitude and $97^{\circ} 04^{\prime}$ west longitude, at an altitude of $151 \mathrm{~m}$ above the sea level. It has an area of $815.13 \mathrm{~km}^{2}$ and represents $1.12 \%$ of the total state land area. The climate in this town is warm-wet-regular with an average temperature of $23.7^{\circ} \mathrm{C}$ and an average annual rainfall of $1293.6 \mathrm{~mm}$.

\subsection{Problem variables}

The variables related to the nature of farming and agricultural practices for the production of Persian lime are described in Table 1, which correspond to their comparative advantages: soil and altitude (mnm); operational variables: orchard pattern, orchard age, cultivation density, cultivation shape; and those concerning the agricultural practices: pruning, application of foliar fertilizers and agrochemical application.

It must be emphasized that a study conducted in Martinez de la Torre, Veracruz reported that most of the producers of Persian lime

\begin{tabular}{|c|}
\hline $\begin{array}{c}\text { Expert panel } \\
\text { integration }\end{array} \rightarrow$ Feeding the SE $\rightarrow \begin{array}{c}\text { Crop scenario } \\
\text { evaluation }\end{array} \rightarrow \begin{array}{l}\text { Interpretation of the } \\
\text { response variables }\end{array}$ \\
\hline
\end{tabular}

Fig. 1. Methodology for identifying behavior patterns in agricultural practices application, in Persian lime orchards.

Table 1

Uncertain parameters and variables related to the cultivation of Persian lime.

\begin{tabular}{ll}
\hline Uncertain parameters & Variables \\
\hline - Hurricane & \\
- Cyclone & - Pruning \\
- Drought & - Soil nutrition \\
- Rainfall (pluvial precipitation) & - Pest control \\
- Wind & - Planting density \\
- Pest & - Trees in production \\
\hline
\end{tabular}


(82\%) do not make use of GAP and only the $30.8 \%$ of the Persian lime plantations satisfy the food safety requirements (Herbert, 2009).

This production system includes variables related to uncontrollable phenomena, which have been identified as "uncertain parameters" and are associated with hurricanes, cyclones, drought, wind, rainfall, pests and weather conditions, even if there may be access to information in advance of these parameters the preventive actions taken by the farmers are mostly ineffective to mitigate their effect on the production and the quality of the fruit in the orchard. Therefore it is important to model their behavior.

Fig. 2 describes the interrelationship and its effect on operating variables (agricultural practices), and the uncertain parameters on the performance and the quality of fruit in the SO.

\subsection{Expert system (ES)}

The ES built by four fuzzy models (FMs) is intended to support the decisions of the Persian lime producer in the administration of his orchard through proper management of the agricultural practices. Three of them are designed according to each of the phenological stages of production of Persian lime to estimate the production yield in tons per harvested hectare (ton ha-1): Bloom
(FM-1), Bud (FM-2), Fruit (FM-3); and the last one (FM-4) to estimate the percentage of fruit to export.

Table 2 describes the agricultural practices, uncertain events and the operative variables defined as input (I) and output (O) elements of the FMs in the ES. Fig. 3 presents the stages of maturity of Persian lime and simultaneously represents the decision levels of the three phenological stages: Bloom, Bud and Fruit.

The first stage is defined as the reproducing state of the plant, where a potential production performance is presumed for the next level of decision process, where the variables of the system (agricultural practices) are again taken into account, thus it is

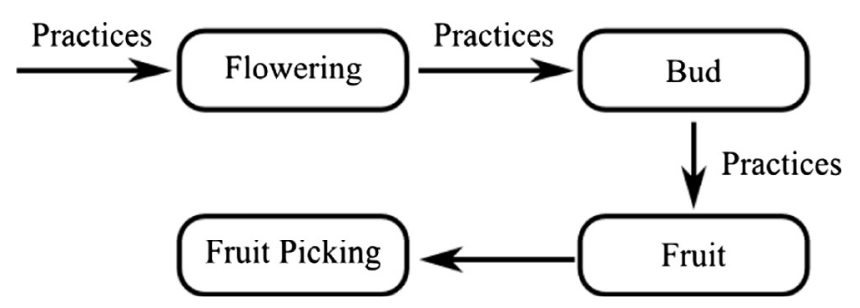

Fig. 3. Stages of maturity of the Persian lime production.

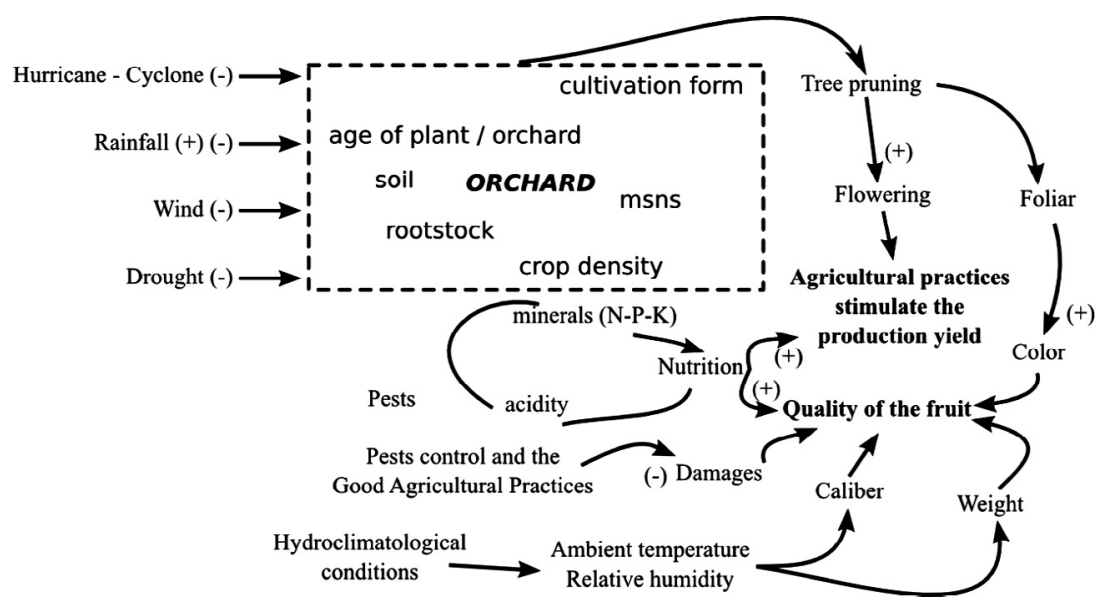

Fig. 2. Variables (GAP) and uncertain parameters related with the production of Persian lime in the seasonal orchard. Source: Fernández et al. (2009).

Table 2

Encoded variables in the knowledge database of the FMs in the ES.

\begin{tabular}{|c|c|c|c|}
\hline Variables & Definition & Measuring unit & Input (I)/output (O) of the FMs \\
\hline Pruning (PyL) & This practice is used to induce flowering & ton ha $\mathrm{h}^{-1}$ & I \\
\hline Soil nutrition $(\mathrm{SN})$ & $\begin{array}{l}\text { Agricultural practice to supply nutrients to the soil and/or leaves } \\
\text { the tree, in order to maximize the production yields and/or fruit quality }\end{array}$ & Number of applications & I \\
\hline Wind $(W)$ & Uncertain event that directly affects the production yield and fruit quality & $\mathrm{km} \mathrm{hr}^{-1}$ & I \\
\hline Rainfall $(R)$ & Uncertain event that provides water to the orchard. & $\mathrm{mm}_{\text {month }}{ }^{-1}$ & I \\
\hline Pests Control (PC) & $\begin{array}{l}\text { Agricultural practice for the control of pests that affect the production yield } \\
\text { and fruit quality }\end{array}$ & Number of applications & I \\
\hline Planting density (PD) & Operation variable that represents the number of trees planted in the orchard & ton ha $\mathrm{h}^{-1}$ & I \\
\hline Tree production (TP) & $\begin{array}{l}\text { Operation variable that represents the number of trees that produce } \\
\text { Persian lime in the orchard }\end{array}$ & ton ha ${ }^{-1}$ & I \\
\hline Performance $(P)$ & $\begin{array}{l}\text { Linguistic expression that represents the performance of } \\
\text { the generated fruit by the orchard }\end{array}$ & ton ha ${ }^{-1}$ & $\mathrm{O}$ \\
\hline Quality Japan (J) & $\begin{array}{l}\text { Linguistic expression that represents the percentage of } \\
\text { fruit quality Japan generated by the orchard }\end{array}$ & $\%$ of production & $\mathrm{O}$ \\
\hline Quality Europa (QE) & $\begin{array}{l}\text { Linguistic expression that represents the percentage of } \\
\text { fruit quality Europe generated by the orchard }\end{array}$ & $\%$ of production & $\mathrm{O}$ \\
\hline Damage $(D)$ & $\begin{array}{l}\text { Linguistic expression that represents the percentage of } \\
\text { damaged fruit generated by the orchard }\end{array}$ & $\%$ of production & $\mathrm{O}$ \\
\hline
\end{tabular}




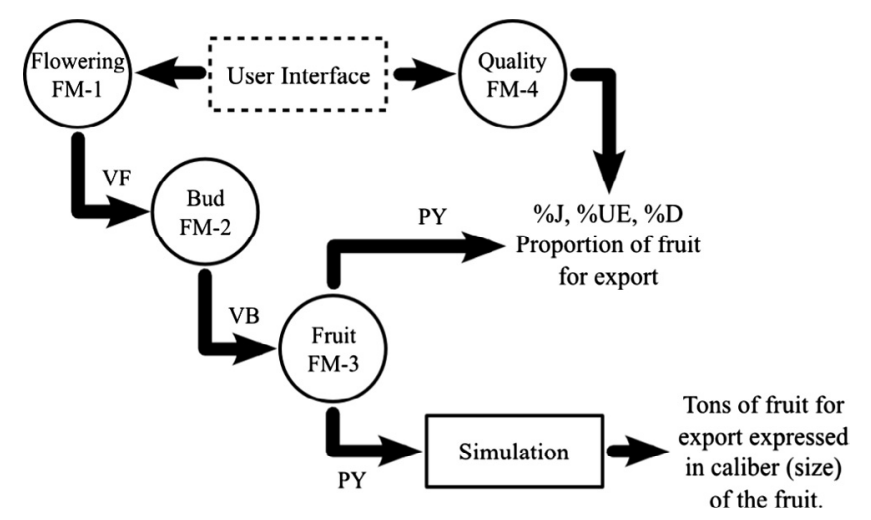

Fig. 4. Characterization of the ES presented by Fernández et al. (2014).

possible to maintain or reduce the condition of the past performance within a management context of the variables and the presence of uncertain events, iteratively until the decision level of the fruit stage. The "Bud" refers to the process in which the "flower" has "curdled" as the fruit. Finally, the phase of fruit refers to the last state where the Persian lime is harvested.

Based on the stages of Persian lime production, the FM-1 starts the ES with the estimation of the volume of flowering (VF). The VF value estimated by the FM-1 feeds among other values of the agricultural practices to the FM-2 to estimate the volume of bud (VB), and successively fed to the FM-3 to finally estimate the volume of production yield (PY) in the orchard.

Moreover, the FM- 4 uses the PY value estimated by the FM-3 in the fruit stage to determine the tons of fruit according to its quality. The FM-4 estimates the percentage of fruit expressed in percent (\%) in quality Japan (J), European Union (EU) and the Persian lime damaged. The quality United States of America (USA) is obtained by the difference of $100 \%$ of the estimated output $\mathrm{J}$, EU and the damaged fruit.

Once the proportion of fruit to export is estimated, the tons of fruit in accordance with the output of the FM-3 (PY) are determined. To estimate the size of the fruit the ES uses a simulation program developed under the environment of PROMODEL ${ }^{\circledR}$ software that models the fruit classification process of an exporting company of citrus and determines the volume of fruit with respect to the size and quality of the fruit in the export market.

As a practical matter, the FM-4 is designed to estimate the global quality of the fruit using the values of the agricultural practices, making it easier for the producer or purchaser of fruit to evaluate the overall quality of the production of the Persian lime in the orchard; with the estimated value obtained by the FM-3, the simulation program promptly estimated the tons of fruit to export, ranking them according to the size of the export requirement. This information helps to the exporter company to improve its decision parameter while selecting the supplier orchard.

Fig. 4 describes the integration of the FMs and the simulation program in the ES. The estimation of PY in the FM-1 is based on 864 inference rules, the FM-2 and FM-3 in 60 rules, and the FM-4 in 54 rules.

The variables have been parameterized and integrated into a knowledge database. The development environment of the ES is performed in MATLAB ${ }^{\circledR}$ 7.0.1, with Mamdani-type inference engine. The rules base is developed under the IF-THEN type and the defuzzification process uses the centroid method. The variables coded in the knowledge database of the FMs are described in Table 2, which are related to agricultural practices, uncertain events, and operational variables defined as inputs elements (I) and output elements $(\mathrm{O})$ of the FMs. The variables are fed according to the FMs of the ES proposed by Fernández et al. (2014), as described in Appendix A. Table A.1 (FM-1), Table A.2 (FM-2), Table A.3 (FM-3); where the variables and fuzzy sets, and the operation values for the fuzzy sets are described.

The results of each "run" represents the simulation stage of the production in the orchard, which allowed to recognize the impact of the agricultural practice as a pattern of behavior of the production yield and the quality of the fruit in the orchard.

More detail regarding to the implementation of the ES in the synchronization of the supply chain of Persian lime can be found in Fernández et al. (2014).

\section{Results and discussion}

To assess the impact of agricultural practices and uncertainties in the Persian lime production yield in the SO described in Table 2, the scenarios presented by Fernández et al. (2014) are modeled.

Table A.1

Fuzzy sets and operation ranges for the fuzzy model of the performance of flowering (FM-1) in the SO.

\begin{tabular}{|c|c|c|c|c|c|}
\hline \multirow[t]{2}{*}{ Input variables } & \multicolumn{2}{|l|}{ Fuzzy sets } & \multirow[t]{2}{*}{ Output variables } & \multicolumn{2}{|l|}{ Fuzzy sets } \\
\hline & Definition & Range & & Definition & Range \\
\hline Planting density (Pd) & $\begin{array}{l}\text { Open } \\
\text { Close } \\
\text { very low }\end{array}$ & $\begin{array}{l}{\left[\begin{array}{llll}0 & 5 & 15 & 20\end{array}\right]} \\
{\left[\begin{array}{llll}15 & 20 & 32 & 32\end{array}\right]} \\
{\left[\begin{array}{llll}0 & 10 & 40 & 60\end{array}\right]}\end{array}$ & & & \\
\hline Tree production (Tp) & $\begin{array}{l}\text { Low } \\
\text { Medium } \\
\text { High }\end{array}$ & $\begin{array}{l}{\left[\begin{array}{lll}40 & 60 & 80\end{array}\right]} \\
{\left[\begin{array}{lll}60 & 80 & 100\end{array}\right]} \\
{\left[\begin{array}{lll}80 & 100 & 100\end{array}\right]}\end{array}$ & & & \\
\hline Pruning (PyL) & $\begin{array}{l}\text { Not done } \\
\text { Aesthetics } \\
\text { Stressful }\end{array}$ & $\begin{array}{l}{\left[\begin{array}{llll}0 & 0 & 3 & 6\end{array}\right]} \\
{\left[\begin{array}{llll}3 & 6 & 15 & 20\end{array}\right]} \\
{\left[\begin{array}{llll}15 & 20 & 32 & 32\end{array}\right]}\end{array}$ & & & \\
\hline Soil nutrition (SN) & $\begin{array}{l}\text { Low } \\
\text { Corrective } \\
\text { Timely }\end{array}$ & $\begin{array}{l}{\left[\begin{array}{llll}0 & 0 & 1 & 2\end{array}\right]} \\
{\left[\begin{array}{llll}1 & 2 & 3 & 4\end{array}\right]} \\
{\left[\begin{array}{llll}3 & 4 & 5 & 6\end{array}\right]}\end{array}$ & Performance of flowering (PF) & $\begin{array}{l}\text { Few-nothing } \\
\text { Very low } \\
\text { Low } \\
\text { Medium } \\
\text { High }\end{array}$ & $\begin{array}{l}{\left[\begin{array}{llll}0 & 0 & 1 & 2\end{array}\right]} \\
{\left[\begin{array}{llll}1 & 2 & 8 & 10\end{array}\right]} \\
{\left[\begin{array}{lllll}8 & 10 & 13 & 15\end{array}\right]} \\
{\left[\begin{array}{lllll}13 & 15 & 20 & 25\end{array}\right]} \\
{\left[\begin{array}{lllll}20 & 25 & 32 & 32\end{array}\right]}\end{array}$ \\
\hline Rainfall $(R)$ & $\begin{array}{l}\text { Low } \\
\text { High }\end{array}$ & $\begin{array}{l}{\left[\begin{array}{llll}0 & 5 & 10 & 50\end{array}\right]} \\
{\left[\begin{array}{llll}10 & 50 & 170 & 170\end{array}\right]}\end{array}$ & & & \\
\hline Pest control (Pc) & $\begin{array}{l}\text { Null-minimum } \\
\text { Protection }\end{array}$ & $\begin{array}{l}{\left[\begin{array}{lll}0 & 0 & 1\end{array}\right]} \\
{\left[\begin{array}{llll}0 & 1 & 3\end{array}\right]}\end{array}$ & & & \\
\hline Wind $(W)$ & $\begin{array}{l}\text { Loose } \\
\text { Hard } \\
\text { Strong }\end{array}$ & $\begin{array}{l}{\left[\begin{array}{llll}0 & 0 & 40 & 50\end{array}\right]} \\
{\left[\begin{array}{lll}40 & 50 & 60\end{array}\right]} \\
{\left[\begin{array}{llll}50 & 60 & 100 & 100\end{array}\right]}\end{array}$ & & & \\
\hline
\end{tabular}


Table A.2

Fuzzy sets and operation ranges for the fuzzy model of the performance of the bud (FM-2) in the SO.

\begin{tabular}{|c|c|c|c|c|c|}
\hline \multirow[t]{2}{*}{ Input variables } & \multicolumn{2}{|l|}{ Fuzzy sets } & \multirow[t]{2}{*}{ Output variables } & \multicolumn{2}{|l|}{ Fuzzy sets } \\
\hline & Definition & Range & & Definition & Range \\
\hline Performance of flowering (PF) & $\begin{array}{l}\text { Few-nothing } \\
\text { Very low } \\
\text { Low } \\
\text { Medium } \\
\text { High }\end{array}$ & $\begin{array}{l}{\left[\begin{array}{llll}0 & 0 & 1 & 2\end{array}\right]} \\
{\left[\begin{array}{llll}1 & 2 & 8 & 10\end{array}\right]} \\
{\left[\begin{array}{lllll}8 & 10 & 13 & 15\end{array}\right]} \\
{\left[\begin{array}{lllll}13 & 15 & 20 & 25\end{array}\right]} \\
{\left[\begin{array}{lllll}20 & 25 & 32 & 32\end{array}\right]}\end{array}$ & & & \\
\hline Soil nutrition (SN) & $\begin{array}{l}\text { Low } \\
\text { Timely }\end{array}$ & $\begin{array}{l}{\left[\begin{array}{lll}0 & 1 & 2\end{array}\right]} \\
{\left[\begin{array}{lll}1 & 2 & 2\end{array}\right]}\end{array}$ & Performance of the bud (PB) & $\begin{array}{l}\text { Few-nothing } \\
\text { Very low } \\
\text { Low } \\
\text { Medium } \\
\text { High }\end{array}$ & $\begin{array}{l}{\left[\begin{array}{llll}0 & 0 & 1 & 2\end{array}\right]} \\
{\left[\begin{array}{llll}1 & 2 & 8 & 10\end{array}\right]} \\
{\left[\begin{array}{lllll}8 & 10 & 13 & 15\end{array}\right]} \\
{\left[\begin{array}{lllll}13 & 15 & 20 & 25\end{array}\right]} \\
{\left[\begin{array}{llll}20 & 25 & 32 & 32\end{array}\right]}\end{array}$ \\
\hline Rainfall $(R)$ & $\begin{array}{l}\text { Low } \\
\text { High }\end{array}$ & $\begin{array}{l}{\left[\begin{array}{llll}0 & 0 & 10 & 50\end{array}\right]} \\
{\left[\begin{array}{llll}0 & 50 & 170 & 170\end{array}\right]}\end{array}$ & & & \\
\hline Wind $(W)$ & $\begin{array}{l}\text { Loose } \\
\text { Hard } \\
\text { Strong }\end{array}$ & $\begin{array}{l}{\left[\begin{array}{llll}0 & 0 & 40 & 50\end{array}\right]} \\
{\left[\begin{array}{lll}40 & 50 & 60\end{array}\right]} \\
{\left[\begin{array}{llll}50 & 60 & 100 & 100\end{array}\right]}\end{array}$ & & & \\
\hline
\end{tabular}

Table A.3

Fuzzy sets and operation ranges for the fuzzy model of the performance of the fruit (FM-3) in the SO.

\begin{tabular}{|c|c|c|c|c|c|}
\hline \multirow[t]{2}{*}{ Input variables } & \multicolumn{2}{|l|}{ Fuzzy sets } & \multirow[t]{2}{*}{ Output variables } & \multicolumn{2}{|l|}{ Fuzzy sets } \\
\hline & Definition & Range & & Definition & Range \\
\hline Performance of the bud (PB) & $\begin{array}{l}\text { Few-nothing } \\
\text { Very low } \\
\text { Low } \\
\text { Medium } \\
\text { High }\end{array}$ & $\begin{array}{l}{\left[\begin{array}{llll}0 & 0 & 1 & 2\end{array}\right]} \\
{\left[\begin{array}{llll}1 & 2 & 8 & 10\end{array}\right]} \\
{\left[\begin{array}{llll}8 & 10 & 13 & 15\end{array}\right]} \\
{\left[\begin{array}{lllll}13 & 15 & 20 & 25\end{array}\right]} \\
{\left[\begin{array}{llll}20 & 25 & 32 & 32\end{array}\right]}\end{array}$ & & & \\
\hline Soil nutrition $(\mathrm{SN})$ & $\begin{array}{l}\text { Low } \\
\text { Timely }\end{array}$ & $\begin{array}{l}{\left[\begin{array}{lll}0 & 1 & 2\end{array}\right]} \\
{\left[\begin{array}{llll}1 & 2 & 6\end{array}\right]}\end{array}$ & Performance of the fruit (Pf) & $\begin{array}{l}\text { Few-nothing } \\
\text { Very low } \\
\text { Low } \\
\text { Medium } \\
\text { High }\end{array}$ & $\begin{array}{l}{\left[\begin{array}{llll}0 & 0 & 1 & 2\end{array}\right]} \\
{\left[\begin{array}{llll}1 & 2 & 8 & 10\end{array}\right]} \\
{\left[\begin{array}{llll}8 & 10 & 13 & 15\end{array}\right]} \\
{\left[\begin{array}{lllll}13 & 15 & 20 & 25\end{array}\right]} \\
{\left[\begin{array}{lllll}20 & 25 & 32 & 32\end{array}\right]}\end{array}$ \\
\hline Rainfall $(R)$ & $\begin{array}{l}\text { Low } \\
\text { High }\end{array}$ & $\begin{array}{l}{\left[\begin{array}{llll}0 & 0 & 10 & 50\end{array}\right]} \\
{\left[\begin{array}{llll}10 & 50 & 170 & 170\end{array}\right]}\end{array}$ & & & \\
\hline Wind $(V)$ & $\begin{array}{l}\text { Loose } \\
\text { Hard } \\
\text { Strong }\end{array}$ & $\begin{array}{l}{\left[\begin{array}{llll}0 & 0 & 40 & 50\end{array}\right]} \\
{\left[\begin{array}{llll}40 & 50 & 60\end{array}\right]} \\
{\left[\begin{array}{llll}50 & 60 & 100 & 100\end{array}\right]}\end{array}$ & & & \\
\hline
\end{tabular}

Fig. 5 shows that the pest control has no contribution to the performance ratio of the production, which does not mean that pests control is not necessary, since it represents a practical protection from the stage of bloom of the fruit. In a production scenario in the SO in which an aesthetic PyL, of $2-3 \mathrm{SN}$, and $R=55 \mathrm{~mm} \mathrm{month}^{-1}$ is achieved, the effect of the wind on the Performance of the SO can be studied through the equation $y=7214 \ln (x)+60.2$. It must be concluded that if the wind speed is low, it is expected that the production would not be affected.

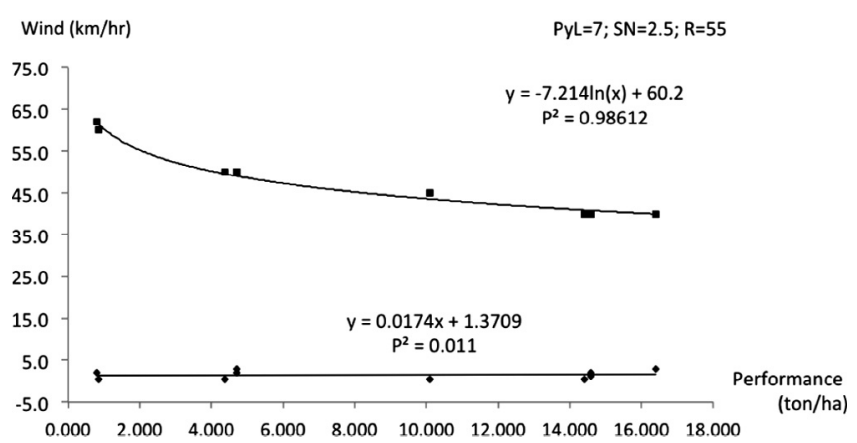

Fig. 5. Impact of wind and pest control in the production of Persian lime in the SO, when the PyL, $\mathrm{SN}=2-3$, and $R=55 \mathrm{~mm} \mathrm{month}^{-1}$ remain constant.
This figure shows that there is an inflection of the production yield around $45 \mathrm{~km} \mathrm{hr}^{-1}$. Low values of production (less than 1 ton ha ${ }^{-1}$ ) are obtained as the wind speed increases.

Fig. 6 shows two production scenarios where the wind $(W)$ is less than or equal to $42 \mathrm{~km} \mathrm{hr}^{-1}$; in this case we can expect an increase in the production due to the relationship between the amount of water and the practice of Pruning (PyL) at the orchard. A similar relationship is observed between 30 and $50 \mathrm{~mm}$ month ${ }^{-1}$. A similar relationship of 6.3 ton ha $^{-1}$ is observed between 30 and $50 \mathrm{~mm} \mathrm{month}^{-1}$, for $\mathrm{PyL}=4$ and $\mathrm{PC}=3$. This occurs under aesthetic pruning and when pest protection is practiced. It can also be seen that when the wind is less than or equal to $42 \mathrm{~km} \mathrm{hr}^{-1}$, in a scenario of $R=50 \mathrm{~mm} \mathrm{month}^{-1}$, and pests protection combat $(\mathrm{PC}=3)$, when performed $\mathrm{PyL}=15$ (aesthetics pruning) to $\mathrm{PyL}=20$ (stressful pruning), its impact on performance (ton ha ${ }^{-1}$ ) improves from 6.98 to 9.21 ton ha ${ }^{-1}$.

The production yield is presented as a function of the agricultural practices where the application of nutrients to the soil is closely related to water so that the applied nutrients increase the production. Fig. 7a shows that for three nutrient applications combined with a rainfall of $20-40 \mathrm{~mm} \mathrm{month}^{-1}$ the production yield can be expected from 13.2 and 15.8 ton ha ${ }^{-1}$ respectively.

The ES highlights that the production can be maintained unchanged even when the number of applications of nutrients 


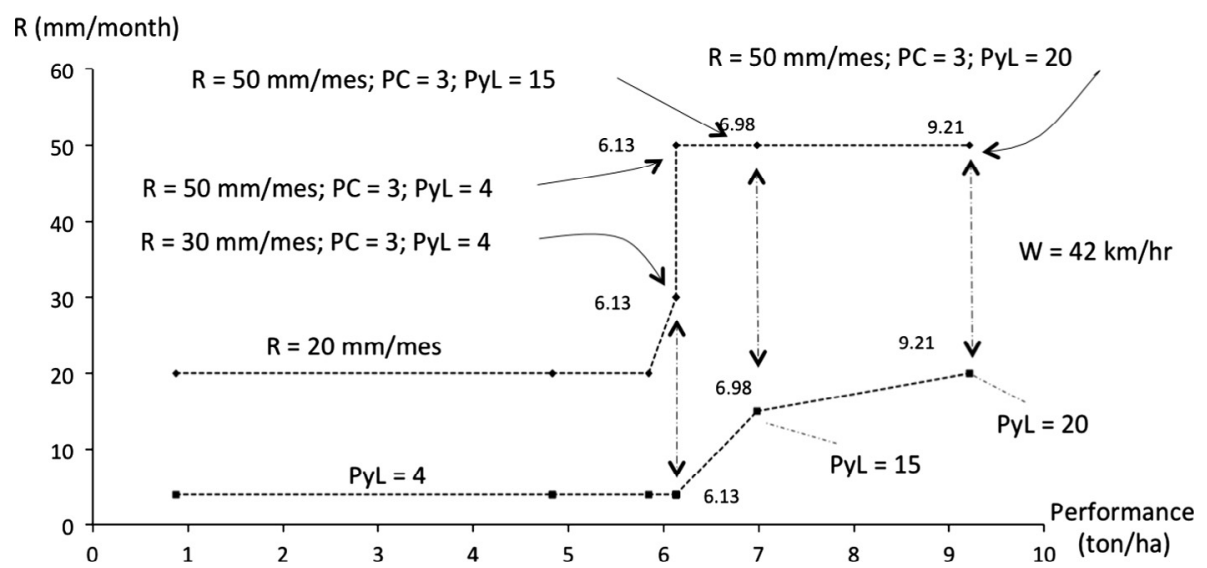

Fig. 6. Pruning (PyL) and rain $(R)$ impact in the production yield of the orchard, when pests protection combat (PC) is maintained, and $W$ is less than or equal to $42 \mathrm{~km} \mathrm{hr}{ }^{-1}$.

Performance (ton/ha)

(a)

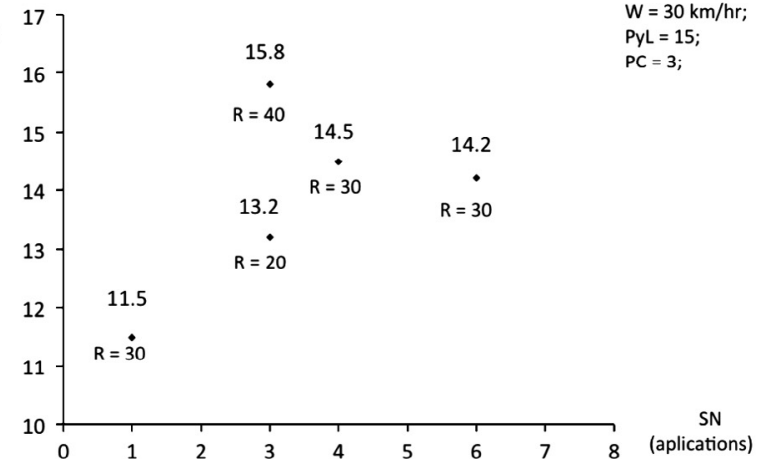

Performance (ton/ha)

(b)

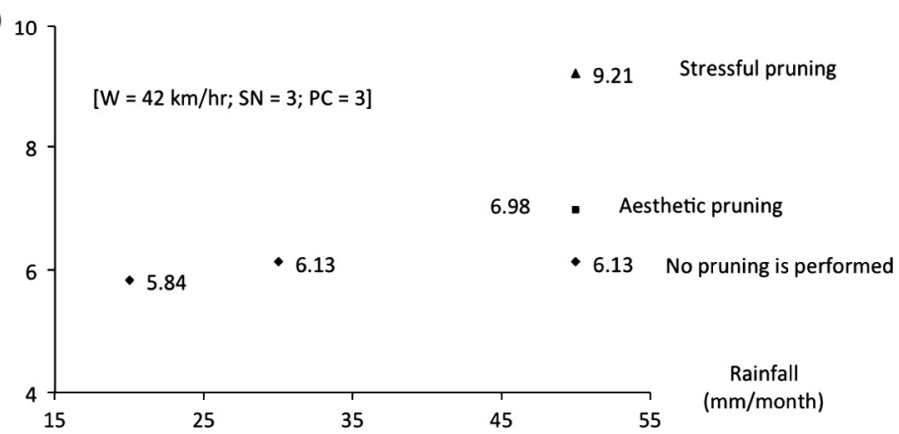

Fig. 7. Effect of soil nutrition and its relationship with water, and the importance of the pruning in the production yield in the SO.

increases, emphasizing the importance of water in combination with the application of nutrients. The ES also explains the relationship of the content of water (pluvial precipitation), soil nutrition and type of pruning practiced in the orchard with its performance; this occurs through a mass transfer mechanism consisting of the input of nutrients in the form of dissolved ions in the water where the efficiency of this transport system depends on the mobility of each element or ion (Aguilera et al., 1996) due to hydric potential generated by transpiration.

Fig. $7 \mathrm{~b}$ presents a scenario in which wind speed is $42 \mathrm{~km}$ with three applications of soil nutrition (SN) and three applications of pest control (PC). It can be observed, on the one hand, that, when the orchard is not pruned, and while the amount of water increases the performance of the orchard is roughly constant. This same practice (pruning) improves the quality of the fruit in its color and size, allowing more light, especially in the bottom of the treetop (Curti-Díaz et al., 2000).

On the other hand, if the same amount of water is used when stressful and aesthetic pruning is carried out, an increase in the production yield of the orchard can be expected. AlmaguerVargas et al. (2011) assessed a treatment (pruning + foliar urea + foliar fertilizer) that reported similar results and show that this combination can lead to a higher production due to the increase in the number of flowers. The ES demonstrates that the pests control is important as a mean to protect the production, even though it does not contribute to production increase. If this is not done the possibility of losing the harvest per pest is high.

Fig. 8 shows that as the pests control is minimized the production yield also decreases. This behavior explain that the effect occurring when one increases the application of nutrients (NS)

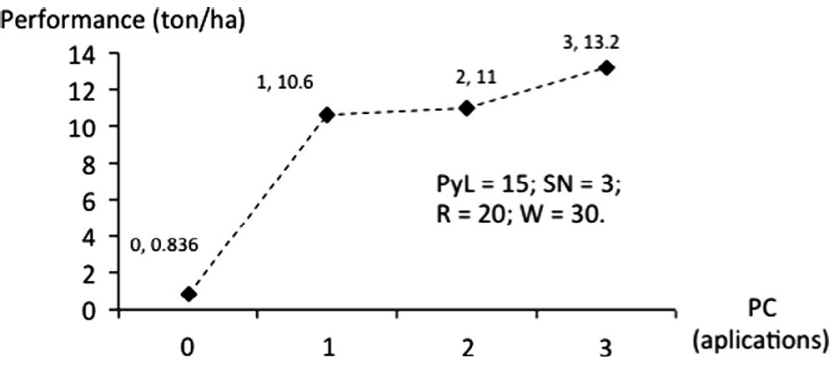

Fig. 8. Relationship between the pests control and the protection of flowering.

on the production yield under a "light wind" with speed less than or equal to $40 \mathrm{~km} \mathrm{hr}^{-1}$ is no more than 2.6 ton ha ${ }^{-1}$, using 1 to 3 applications of nutrients.

The ES for the prediction of the production yield in the flowering stage appropriately responds to the expertise under which it was designed. For the bud stage, Fig. 9 shows the behavior that explains the degree of relationship of the benefits when the nutrients are applied with water and allows us to appreciate that the higher nutrient application provides greater performance benefit of the production. Nutrition and water work together for the benefit of the production yield. This figure shows that there is a better effect of the nutrients with a rainfall greater than $110 \mathrm{~mm} \mathrm{month}^{-1}$.

The effect of nutrient application can be explained linearly with a determination coefficient of $97.97 \%$, wherein, every $\mathrm{mm} \mathrm{month}^{-1}$ of rainfall on a prediction of 20 ton month ${ }^{-1}$ in relation to four 


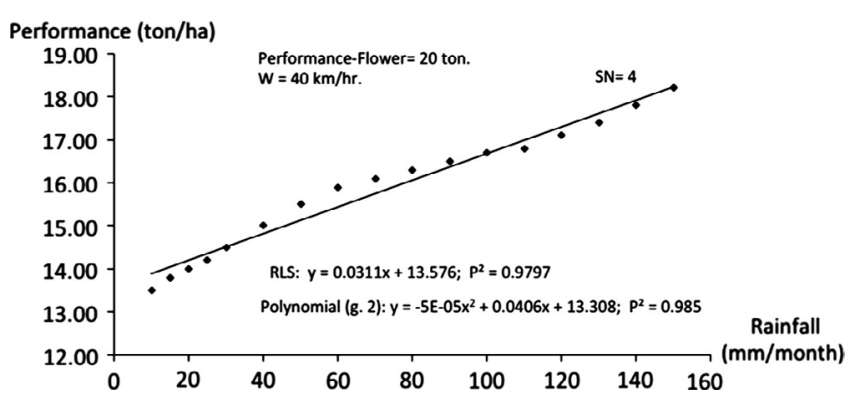

Fig. 9. Correlation of the production yield (ton ha ${ }^{-1}$ ) given by the effect of the rainfall $\left(\mathrm{mm}\right.$ month $\left.^{-1}\right)$.

applications of nutrients and wind of $40 \mathrm{~km} \mathrm{hr}^{-1}$, would have an impact of 0.0311 ton $\mathrm{ha}^{-1}$ on the production yield. The effect of nutrient application can also be studied with second-degree polynomial behavior with a determination of $98.5 \%$.

In Fig. 10a, it can be seen that the production yield increases as the number of applications of nutrients and water also increase. Fig. 10b shows that the production yield can be explained by $y=0.9536 x+11.868$ with a determination of $98.17 \%$ in scenarios where the rainfall $\left(\mathrm{mm}\right.$ month $\left.^{-1}\right)$ remains constant at different levels of nutrient application.

Fig. 11 describes the behavior of the ES in a scenario where the wind has a speed between 30 and $50 \mathrm{~km} \mathrm{hr}^{-1}$ with different levels of soil nutrition (SN), 1-6 applications, with a rainfall of $50 \mathrm{~mm}$ month $^{-1}$. The results reveal that the wind with a speed of $40 \mathrm{~km} \mathrm{hr}^{-1}$ causes no damage to the production; however above this value the wind begins to have a negative effect on it, making it drop to levels below one ton per hectare or no production at all.

We can also see that in scenarios where the $\mathrm{SN}$ is between 1 and 3 with a wind speed between 46 and $48 \mathrm{~km} \mathrm{hr}^{-1}$ the prediction of

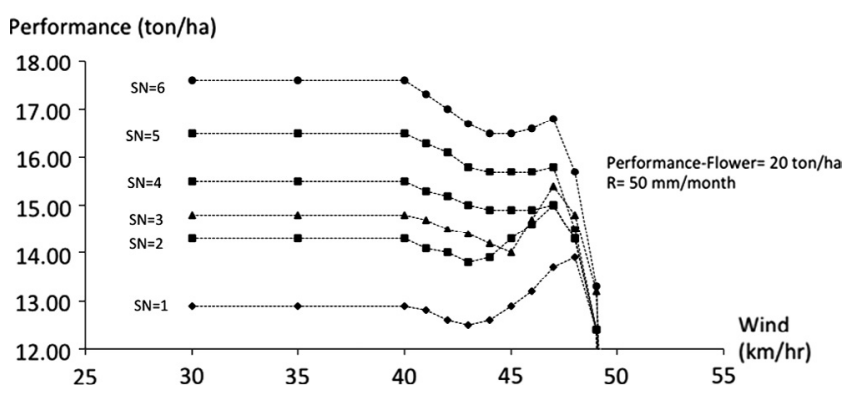

Fig. 11. Correlation of the production yield $\left(\right.$ ton ha ${ }^{-1}$ ) given by the effect of the wind $\left(\mathrm{km} \mathrm{hr}^{-1}\right)$.

the performance is not similar to those scenarios where the $\mathrm{SN}$ is between 4 and 6 with the same wind speed. This behavior can be explained by the range of prediction that takes the output variable given by the group of expert. In numerical terms, it has a variation in the prediction of no more than 0.3 ton ha ${ }^{-1}$.

The ES for the performance prediction of the production in the bud stage corresponds appropriately to the expertis under which it was designed. Based on the opinion of the experts, the design of this ES also corresponds to the fruit stage. This is justified whenever the orchard system variables and uncertain events defined for these stages have the same effect in determining the production yield of the orchard for both scenarios.

The ES for fruit quality proves the importance of combining the soil nutrition and water to benefit the quality of the fruit. Fig. $12 \mathrm{a}$ and $\mathrm{b}$ show that the wind $(W)$ with a speed greater than $41 \mathrm{~km} \mathrm{hr}^{-1}$ has a negative impact that decreases the performance of the quality of the fruit. When the wind is less than $40 \mathrm{~km} \mathrm{hr}^{-1}$, in rain dry atmosphere $\left(P=20 \mathrm{~mm} \mathrm{month}^{-1}\right)$, and three applications of fertilizer to soil ( $\mathrm{NS}=3$ ) are performed, in Fig. 12a can be

Performance (ton/ha)

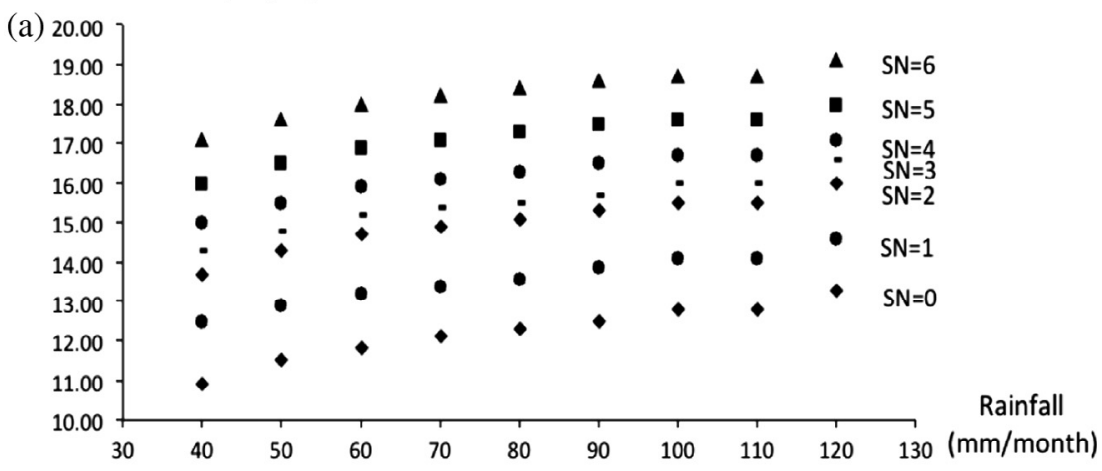

Performance (ton/ha)

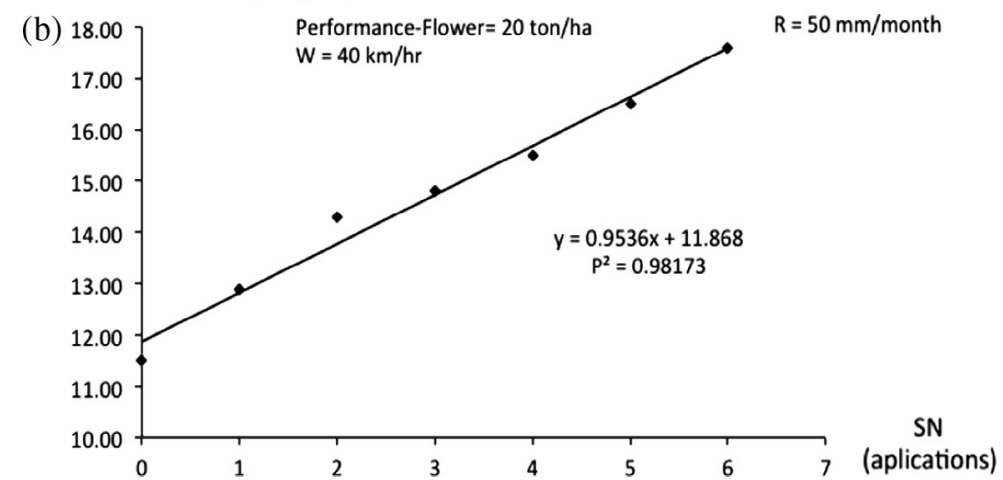

Fig. 10. Correlation of the production yield (Performance ton ha $\left.{ }^{-1}\right)$ given by the effect of the rainfall $\left(\mathrm{mm} \mathrm{month}^{-1}\right)$. 


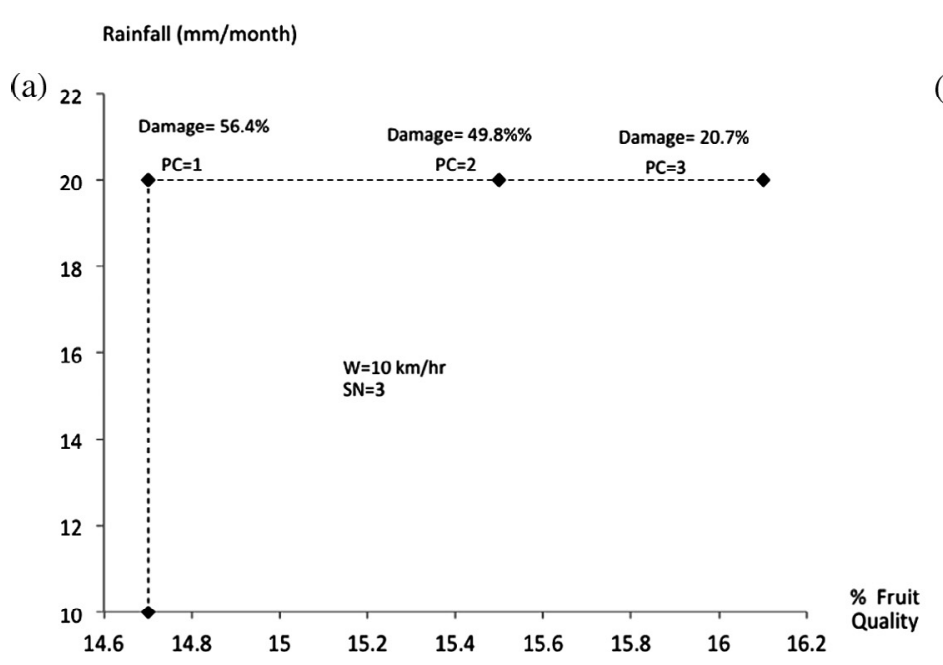

(b)

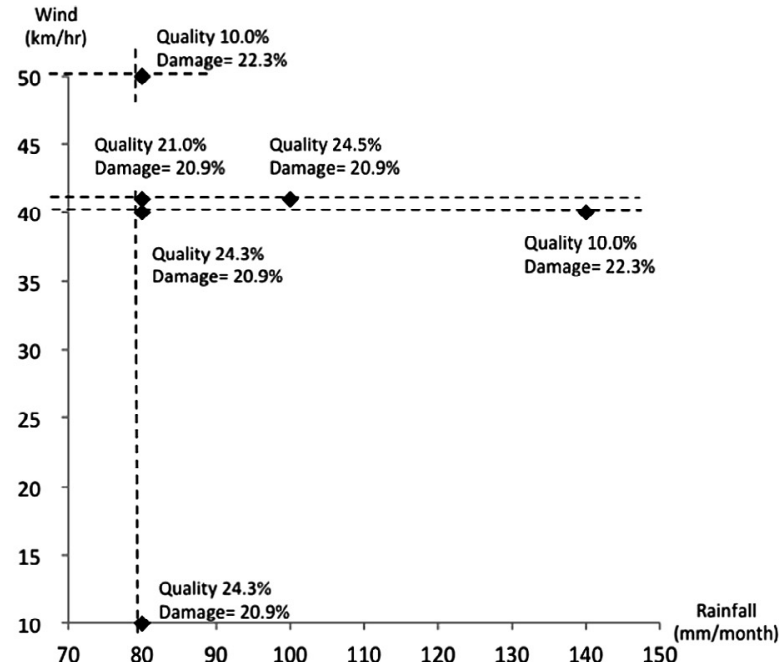

Fig. 12. Effect of the rainfall and wind over the quality of the fruit

Table A.4

Fuzzy sets and operation ranges for the fuzzy model of the performance of the quality (FM-4) in the SO.

\begin{tabular}{|c|c|c|c|c|c|}
\hline \multirow[t]{2}{*}{ Input variables } & \multicolumn{2}{|l|}{ Fuzzy sets } & \multirow[t]{2}{*}{ Output variables } & \multicolumn{2}{|l|}{ Fuzzy sets } \\
\hline & Definition & Range & & Definition & Range \\
\hline Pest control (Pc) & $\begin{array}{l}\text { Null-minimum } \\
\text { Low } \\
\text { Basic }\end{array}$ & $\begin{array}{l}{\left[\begin{array}{lll}0 & 0 & 1\end{array}\right]} \\
{\left[\begin{array}{lll}0 & 1 & 2\end{array}\right]} \\
{\left[\begin{array}{llll}1 & 2 & 3 & 3\end{array}\right]}\end{array}$ & Japan (JP) & $\begin{array}{l}\text { Minimum } \\
\text { Low } \\
\text { High }\end{array}$ & $\begin{array}{l}{\left[\begin{array}{llll}0 & 0 & 1 & 2\end{array}\right]} \\
{\left[\begin{array}{llll}1 & 2 & 10 & 20\end{array}\right]} \\
{\left[\begin{array}{lllll}10 & 15 & 30 & 30\end{array}\right]}\end{array}$ \\
\hline Soil nutrition (SN) & $\begin{array}{l}\text { Low } \\
\text { Corrective } \\
\text { Timely }\end{array}$ & $\begin{array}{l}{\left[\begin{array}{llll}0 & 0 & 1 & 2\end{array}\right]} \\
{\left[\begin{array}{llll}1 & 2 & 3 & 4\end{array}\right]} \\
{\left[\begin{array}{llll}3 & 4 & 6 & 6\end{array}\right]}\end{array}$ & European Union (EU) & $\begin{array}{l}\text { Minimum } \\
\text { Low } \\
\text { High }\end{array}$ & $\begin{array}{l}{\left[\begin{array}{llll}0 & 0 & 1 & 2\end{array}\right]} \\
{\left[\begin{array}{llll}1 & 2 & 10 & 20\end{array}\right]} \\
{\left[\begin{array}{lllll}10 & 20 & 25 & 25\end{array}\right]}\end{array}$ \\
\hline Rainfall $(R)$ & $\begin{array}{l}\text { Low } \\
\text { High }\end{array}$ & $\begin{array}{l}{\left[\begin{array}{llll}0 & 0 & 10 & 50\end{array}\right]} \\
{\left[\begin{array}{llll}10 & 50 & 170 & 170\end{array}\right]}\end{array}$ & Damages $(D)$ & $\begin{array}{l}\text { Low } \\
\text { High }\end{array}$ & $\begin{array}{l}{\left[\begin{array}{llll}0 & 0 & 6 & 10\end{array}\right]} \\
{\left[\begin{array}{llll}6 & 20 & 30\end{array}\right]}\end{array}$ \\
\hline Wind $(W)$ & $\begin{array}{l}\text { Loose } \\
\text { Hard } \\
\text { Strong }\end{array}$ & $\begin{array}{l}{\left[\begin{array}{llll}0 & 0 & 40 & 50\end{array}\right]} \\
{\left[\begin{array}{lll}40 & 50 & 60\end{array}\right]} \\
{\left[\begin{array}{llll}50 & 60 & 100 & 100\end{array}\right]}\end{array}$ & & Damages & {$\left[\begin{array}{lllll}20 & 40 & 100 & 100\end{array}\right]$} \\
\hline
\end{tabular}

seen, that pests protection combat (PC) minimizes fruit damage according PC increases, and as a result, production quality is improved. However, even if a $\mathrm{SN}=3$ is maintained, and millimeters of water are increased, Fig. 12b shows that if the PC is not performed, production quality and fruit damage decreases and increases respectively. This same effect can be observed if the wind exceeds $45 \mathrm{~km} \mathrm{hr}^{-1}$.

\section{Conclusions}

Worldwide, the agricultural field has been studied in order to improve production results. There have been many academic works that require its application in orchards in order to evaluate the results of the implementation of practical proposals for improving production yield and product quality.

This study reports an approach based on the use of an ES which begins with pattern recognition related to the use and combination of agricultural practices for the production of Persian lime on a seasonal orchard, with the aim of modeling production yield and fruit quality scenarios.

The study of the correlation of agricultural practices in the expert system, normally used as in any agricultural field, has been codified in a knowledge database in order to understand the impact of practices in the production of Persian lime, and evaluate the results without applying them in the orchard production.

The ES presented by Fernández et al., 2014, demonstrates that agricultural practices in the Persian lime production on a seasonal orchard are related to specific application intervals while seeking to have a greater impact on production yield or improvement of fruit quality.

Contrary to the traditional idea of the producer relying determinedly on fertilization to improve production yield and fruit quality, modeling scenarios reveals that production yield has better results when prior to fertilization, the practice of "prunning" the tree is performed.

While water is a determining variable in any agricultural production system, the ES reveals that it has its greatest contribution when performed three to four fertilizer applications in the production cycle of Persian lime; and a greater number of these applications, their impact on the production yield and the quality of the fruit, is not significant.

The combination of agricultural practices in the production of Persian lime has a different impact on each stage of production, particularly in a seasonal orchard, modeling scenarios at the flowering stage shows that better results are obtained when the rain is between 40 and $50 \mathrm{~mm} \mathrm{month}^{-1}$, combined with nutrition to the ground; while for the but stage as the fruit stage, the best results are with a rainfall between 55 and $60 \mathrm{~mm} \mathrm{month}^{-1}$, combined with two SN.

Strictly at each stage, pest protection combat in two applications is sufficient. A greater number of PC applications is up to the producer to protect his crop, without expecting them to improve production yield on the orchard. Clearly the rain parameter cannot be controlled in an seasonal orchard, however, this 
information is useful for irrigation orchards. In this sense, the implementation of the type and quantity of agricultural practices underscores the importance of economic cost-benefit assessment concerning the expected results of production yield and fruit quality.

The results presented in this article, provide a robust framework that the proposed approach aids the producer to improve the decision-making process in the orchard management, knowing prior to the implementation of its agricultural practices, the impact and the relationship between the system variables, and in a broad sense, this study approach can be extended to other agricultural production systems, not only to simulate production scenarios from agricultural practices management, but also for the purpose of synchronizing the supply chain in the agricultural sector.

In an innovative attempt, the main contribution of this work is the expert system approach aiming at improving production yield in fresh products orchards from the identification of behavior patterns based on the agricultural practices used by the farmer. This particular contribution to Persian lime production uses artificial intelligence techniques as a predictive instrument to control work variables in agricultural machinery or to control work atmospheres; such systems are yet not accessible to the vast majority of small producers. In this approach, the user only needs to have data of agricultural practices and simulate possible work scenarios in the expert system.

The development of an expert system yet requires the clear specification of the domain. The expert system used in this work is designed by experts in the production of Persian lime, and can be adapted to citrus production scenarios. Furthermore, the expert system may include new or different knowledge of the crop system variables under study.

\section{Acknowledgments}

We thank the CONACYT-Research Network in the area of Systems Transport and Logistics (SiT-LOG); Export Company San Gabriel, S.A. of C.V., and the National Research Institute of Forestry, Agriculture and Livestock of the Experimental Ixtacuaco field in Mexico by support provided during the realization of this research.

\section{Appendix A}

The criteria defined in the ES proposed by Fernández et al. (2014), correspond to crop variables and agricultural practices in Persian lime production, which include uncertain events such as weather and hydro-climatic conditions, focused on the estimation of production and quality performance in the orchard. Basically, as you can see in Fig. 2, ES raises the relationship between variables of the Persian lemon production system in orchard and shows a group of uncertain variables, not controlled by the producer, however potentially present in the production system. This is the importance of modeling their behavior. The knowledge base of the ES categorized variables embedded in the Persian lemon production in two hierarchies. The first one corresponds to the criteria of the orchard production performance and the second hierarchy to those related to the harvested fruit quality. Both criteria refer to variables related to good agricultural practices which should prevail as part of the maintenance of the orchard; and in other hand uncertain parameters, only you can model that behavior.

The ES integrates the stages of the production cycle reported in Fig. 2: flowering (FM-1), bud (FM-2), fruit (FM-3). The first stage of production (flowering) boasts production performance to the next level of production (bud), in which are involved agricultural practices that will maintain or decrease, within a context of implementing agricultural practices and the presence of uncertain events, the performance of FM-1 stage production, and so on to the stage of fruit.

For each of these stages of the production cycle, Fernández et al. (2014) design a ES based on FMs, which are described in the Tables A.1-A.3, which is modeled the ability which has a seasonal garden to produce fruit, expressed in tons per hectare. Likewise, the Table A.4, presents the FM- 4 which estimated the fruit quality from the export market fruit quality characteristics. Particularly this FM-4 calculate the percentage of fruit with Japan, and Europe quality.

Tables A.1-A.4 describe the operating values for the fuzzy sets of the FMs of flowering, bud, and fruit quality. To get more information regarding the expert system used in this work, the reader should consult Fernández et al. (2014): An expert system for predicting orchard yield and fruit quality and its impact on the Persian lime supply chain, Engineering Applications of Artificial Intelligence, ISSN 0952-1976, 33: 21-30 http://dx.doi.org/10. 1016/j.engappai.2014.03.013.

\section{References}

Aguilera, C.M., y Martínez, E.R., 1996. Relaciones agua, suelo, planta, atmósfera. Editorial. Universidad Autónoma Chapingo, Estado de México.

Agustí, M., Mesejo, C., Reig, C., Martínez-Fuentes, A., 2014. Citrus production. Horticulture Plants for People and Places, vol. 1. Springer, Netherlands, pp. 159195.

Almaguer-Vargas, Gustavo, Espinoza-Espinoza, José Refugio, Quirós-García, José Luís., 2011. Desfasamiento de cosecha de limón persa, Revista Chapingo. Serie horticultura, 17(3), 197-205. Recuperado en 11 de julio de 2014, de <http:// www.scielo.org.mx/scielo.php?script=sci_arttext\&pid=S1027-152X2011000300 $011 \& \operatorname{lng}=$ es\&tlng=es $>$

Anido, D., 1998. Sistema Lineal del gasto: Especificación y Estimación para la Ciudad de Mérida, 1986. Universidad de Los Andes, Mérida, Venezuela.

Aranguren Pachano, Liz Jeannette, 2008. Identificación de patrones de consumo de los venezolanos mediante Máquinas de Vectores Soporte. Proyecto de grado, Universidad de Los Andes, Venezuela.

Ayman Nada, Mona Nasr, Maryam Hazman, 2014. Irrigation expert system for trees. Int. J. Eng. Innovat. Technol. (IJEIT) 3 (8), 2277-3754.

Bazan, Jan G., 2005. Behavioral pattern identification through set modeling. Fundamenta Informaticae 72 (1-3). Amsterdam, ISSN: 0169-2968.

Becerra, Durán J.A., Gregorio Fernández Lambert, José Luis Martínez Flores, y Alberto A. Aguilar Lasserre, 2009. Caracterización de la cadena de suministros de los cítricos en el Estado de Veracruz, Reporte de Investigación, Universidad Popular Autónoma del Estado de Puebla, México.

Carr, M.K.V., 2012. The water relations and irrigation requirements of citrus (Citrus spp.): a review. Exp. Agric, 48 (03), 347-377.

Chacín, A.E.C. Bonafine, O., Méndez, J.R., 2012. Crecimiento, desarrollo y calidad del fruto de Lima 'Tahití' (Citrus latifolia Tanaka) en el Estado Monagas, Venezuela. Revista Científica UDO Agrícola 12 (3), 535-541.

Chakraborty, P., Chakrabarti, D.K., 2008. A brief survey of computerized expert systems for crop protection being used in India. Prog. Nat. Sci. 18 (4), 469-473.

Chevalier, R.F., Hoogenboom, G., McClendon, R.W., y Paz, J.O., 2012. Un sistema experto difuso basado en la web para las advertencias de heladas en los cultivos hortícolas. Modelado y software 35, 84-91. Ambiental.

Consoli, S., Stagno, F., Roccuzzo, G., Cirelli, G.L., Intrigliolo, F., 2014. Sustainable management of limited water resources in a young orange orchard. Agric. Water Manag. 132, 60-68. http://dx.doi.org/10.1016/j.agwat.2013.10.006.

Corrales-García, J., Cruz-Castillo, J.G., Lozano-Lopez, E., Famiani, F., 2009. Technological conditions in orchards of Persian line (Citrus latifolia Tan.) for the Japanese market in Veracruz, Mexico. J. Agr. Univ. Puerto Rico 93 (1/2), 143147.

Curti, Díaz, S.A., Xóchitl Loredo Salazar, Ulises Díaz Zorrilla, José A. Sandoval Rincón y Juan Hernández Hernández, 2000. Tecnología para la producción de Limón Persa, Instituto Nacional de Investigaciones Forestales, Agrícolas y Pecuarias (INIFAP), INIFAP, México.

Curti-Díaz, S.A., Loredo-Salazar, X., Díaz-Zorrilla, U., Sandoval, R.YJ., Hernández, H., 2000. Tecnología para producir limón Persa. INIFAP-CIRGOC. Campo Experimental Ixtacuaco. Libro Técnico No. 8 Veracruz, México.

Dath, Ani, Balakrishnan, M., 2013. Development of an expert system for agricultural commodities. Int. J. Comp. Sci. Appl. (TIJCSA) 2 (07), ISSN - 22781080.

FAO (2010) -Food and Agriculture Organization-, obtenido de la Red Mundial, Recuperado el 12 de mayo de 2010, de <http://www.faosfat.org> I (c) FAO Dirección de Estadística 2010.

Fernández, Lambert G., Alberto A. Aguilar Lasserre, Blan O. Ixmatlahua Rivera, Nayeli Montalvo Rivero, 2009. Una propuesta basada en técnicas de la IA para seleccionar proveedores en una exportadora de cítricos, Congreso de Investigación de Academiajournals (CIAJ), 15 y 16 de Octubre, Volumen II 
Ingeniería Industrial, ISSN 1946-5351 (Online), ISSN 1948-2353 (CD ROM), Boca del Río, Veracruz, México. pp. 47-54.

Fernández, Lambert Gregorio, Lasserre, Alberto Alfonso Aguilar, Ackermanc, Marco Miranda, Sánchez, Constantino Gerardo Moras, Rivera, Blanca Olivia Ixmatlahua, Azzaro-Pantel, Catherine, 2014. An expert system for predicting orchard yield and fruit quality and its impact on the Persian lime supply chain. Eng. Appl. Artif. Intel., ISSN 0952-1976 (33), 21-30.

González Cruz, F., 2011. Compilación bibliográfica del limón persa (Citrus latifolia). (Trabajo Recepcional). Universidad Veracruzana. Facultad de Ciencias Químicas. Orizaba. Veracruz-México.

Gupta, Shalabh, 2006. Behavioral Pattern Identification for Structural Health Monitoring in Complex Systems. The Pennsylvania State University, Pennsylvania, USA. AAT 3231837, ISBN: 9780542842825.

Herbert Ruiz, M., 2009. La inocuidad alimentaria en el mercado Mexicano de Limón Persa (Citrus latifolia tanaka), Tesis Doctoral en Socioeconomía, Estadística e Informática Economía. Colegio de Postgraduado. Montecillo, Texcoco, Edo. de México.

Miranda-Ackerman, M.A., Fernández-Lambert, G., Azzaro-Pantel, C., AguilarLasserre, A.A., 2014. A Multi-Objective Modelling and Optimization Framework for Operations Management of a Fresh Fruit Supply Chain: A Case Study on a Mexican Lime Company, in: Valadi, J., Siarry, P. (Eds.), Applications of Metaheuristics in Process Engineering. Springer International Publishing, pp. 373-394.

Neto, H.B., Mourão Filho, F.D.A.A., Stuchi, E.S., Espinoza-Núñez, E., Cantuarias-Avilés, T., 2013. The horticultural performance of five 'Tahiti' lime selections grafted onto 'Swingle'citrumelo under irrigated and non-irrigated conditions. Sci. Hortic. 150, 181-186.

Papageorgiou, E.I., Markinos, A.T., Gemtos, T.A., 2011. Fuzzy cognitive map based approach for predicting yield in cotton crop production as a basis for decision support system in precision agriculture application. Appl. Soft Comput. 11 (4), 3643-3657.

REVIDEC, 2003. -Colegio de Postgraduados, y Fundación Produce de Veracruz, A.C.Necesidades de investigación y transferencia de tecnología de la cadena productiva del limón persa en el Estado de Veracruz, Tepetates, VeracruzMéxico.

Romualdo, L.M., Luz, P.H.C., Devechio, F.F.S., Marin, M.A., Zúñiga, A.M.G., Bruno, O.M., Herling, V.R., 2014. Use of artificial vision techniques for diagnostic of nitrogen nutritional status in maize plants. Comput. Electr. Agr. 104, 63-70.

Shafinah, K., Sahari, N., Sulaiman, R., Soyapi, M., Yusoff, M., Ikram, M., 2013. A framework of an expert system for crop pest and disease management. J. Theor. Appl. Info. Technol. 58 (1).

Srivastava, A.K., 2012. Integrated nutrient management in citrus. In: Advances in Citrus Nutrition. Springer, Netherlands, pp. 369-389.

Syvertsen, J.P., Garcia-Sanchez, F., 2014. Multiple abiotic stresses occurring with salinity stress in citrus. Environ. Exp. Bot. 103, 128-137. http://dx.doi.org/ 10.1016/j.envexpbot.2013.09.015.

Wankhede, S.S., Gandhi, N., Armstrong, L.J., 2014. Application of exper systems in agriculture. Int. J. Pure Appl. Res. Eng. Technol. 3 (1), 86-94, 2319-507X 